\title{
Cultural Intersections and Identity in Algeria on the Eve of the French Invasion
}

\author{
The Case of the Bey Palace in Constantine
}

The palace of the Bey of Constantine was built between 1826 and the mid-1830s, just before the French colonial troops took over the Algerian city. In this paper, we propose to distinguish three periods in the cultural history of this remarkable architectural grouping of buildings and courtyard gardens: beylical until 1837; colonial from 1837 to 1962; national thereafter. Three different sets of political and aesthetic aims correspond to these periods. At the time of its construction, the monument was deliberately conceived as a building characterized by its cultural intersections, mixing together Maghrebi, Ottoman, and European materials, techniques, and stylistic traits. In direct opposition to this approach, the French military administration juxtaposed acts of destruction and salvaging, resulting in heavy visual discrepancies typical of colonial cultural contradictions. Nowadays, the will to restore a perceived "authentic Ottoman" state of the building, purged from its colonial appendices, leads to the paradoxical collision of a fixed authenticity and the reality of a fluid mélange. As we identify these three successive strata of intentions, we ask whether a self-conscious process of patrimonialization can preserve a poetics of hybridity, with the sense of life in forms and space it implies for the visitors of today.

At the end of the eighteenth century, the areas controlled by the Ottoman Empire in the Maghreb were organized into three regencies: Algeria, Tunisia, and Tripoli. The Algerian Regency, governed by a Dey, is itself made up of three beylics, the Eastern one (with its capital, Constantine), the central one, Titteri (with its capital Medea), and the Western one (with its capital Oran); added to this is the "domain of the Sultan" (Dar es-Soltane, around Algiers).

The Constantine Beylic is, like the Oran Beylic, a territory that owes its wealth to the export of wheat; since antiquity, when Africa nova was considered "the granary of Rome," great quantities of it left the ports of Algiers, Cherchell, Dellys, Bejaïa, and Annaba. Although the story of this activity goes back a long way, it is for Europeans certainly "the image of the pirate-nest" ${ }^{1}$ that prevails during Ottoman rule, from 1520 to 1830 . However, the wheat trade is profitable enough to be seen by the trade companies and the French state as worthy of interest; in the eighteenth century, while trading revenue is in decline, "Algeria reveals itself to be capable of moving on from a mainly predatory activity (the resale of piracy booty) to another economic activity:

1 Ismet Touati, Le Commerce du blé entre l'Algérie et la France XVI -XIX' (Paris: Bouchène, 2018). 
the export of its own production, beginning with wheat."2 The country's increase in wealth materializes with the construction of numerous palaces in Algiers and with the embellishment of the town of Constantine led by Salah Bey and his successor Ahmed Bey. In spite of the decline in this revenue from the French Revolution on, a tendency that is to continue till the beginning of the nineteenth century, it is still the wheat trade that enables the rich landowner that was Ahmed Bey-according to the evidence of the Duke of Rovigo in 1832-to buy large quantities of marble and decorated earthenware tiles in Italy for the construction of his palace, through the Genovese wheat-merchant Schiafino. The French army, after failing a first time in 1836, finally seizes Constantine under the command of General Valée, the future general-governor of Algeria, on October 13, 1837. This defeat signals the end of a centuries-old world that was marked by an intensive commercial and cultural flow.

The last years of the Beylic, and those immediately after the fall of Constantine, are deeply marked by the charismatic figure of Ahmed Bey (1787-1850). Two Arabian authors of the time ${ }^{3}$ and two contemporary historians, Abdeljelil Temimi and Abdelkrim Badadja, ${ }^{4}$ make up our main sources of information on the career and personality of the Bey. According to Badadja, the grandfather of Hadj Ahmed Bey, Ahmed Bey El Kolli was a Turk who ruled over Constantine from 1756 to 1771. Ahmed Bey's father, Mohamed Chérif, khalifa (lieutenant) of the Bey Hossein from 1792 to 1795, was a koulougli (of Turkish father and Algerian mother); as for his mother, Hadja Rokia, she descended from the powerful Bengana tribe. She had a determining role in the upbringing of her son, encouraging him toward the Ottoman administration in Istanbul known as the Sublime Porte. At eighteen, in 1805, he is named Caiid el Aouassi (Chief of the Haracta) by Abdallah Bey and is to have the same function under Naâmane Bey, then under Tchaker Bey. He makes the pilgrimage to Mecca, to which he owes his name of "Hadj," and stays several months in Egypt. In 1818, thanks to the backup of Hussein, the Dey of Algiers, Ahmed rises to the rank of khalifa and takes the name of Ahmed Bey El Mamelouk. Having become of some importance in the Beylic, he begins to manage affairs in place of the Bey, which is not met with a kind eye. He has to leave Constantine and takes refuge in Algiers, where he resides between 1819 and 1826, taking advantage of the protection of Dey Hussein. During the earthquake in 1825 at Blida, Ahmed distinguishes himself by his courage and organizational sense for the emergency care. He gains, in this way, the esteem of Dey Hussein, who chooses

2 Ibid., 9.

3 Hamdane Khodja, Aperçu historique et statistique sur la régence d'Alger (titled Le Miroir in Arabic), French trans. H. D. (Paris: de Goetschy, 1833); Salah Al Antri, arida Mounissa. La perle agréable (Constantine: Gueude, 1852), Fr. trans. in Recueil des notices et mémoires de la Société archéologique de la province de Constantine (Constantine, 1863).

4 Abdeljelil Temimi, “Le Beylik de Constantine et Hadj Ahmed Bey, 1830-1837," Revue d'histoire maghrébine, vol 1 (1978); Abdelkrim Badadja, La bataille de Constantine 1836-1837 (Paris: Edilivre, 2011). 
him as Bey of Constantine in August 1826, succeeding to the fickle Bey Manamani. After the fall of Constantine, Ahmed Bey continues to lead the resistance against the French occupation. Forced to surrender in June 1848, he dies in captivity in Algiers on August 30, 1850, and is buried at the Sidi Abderrahmane zaouia (religious establishment) in Algiers, leaving three widows and two daughters.

In the context of the struggle against the French conquest of Algeria, Hadj Ahmed Bey is a very significant personage, only comparable to that of Abd-el-Kader, with whom deep strategic, political, and personal differences had been fatal for unity and for the success of the Algerian resistance to the invader. Unlike Abd-el-Kader, eager for the creation of a modern State, the last Bey of Constantine based his policy on loyalty to the Sublime Porte. His letters to the Sultan are indeed a testimony to his attachment to the Ottoman system, for fulfilling his ambitions. On September 16, 1833, for example, he asks the Sultan to validate the title of pasha that the nobles wished to see him adopt, in the light of his behavior after the conquest of Algiers. It is at this time that he rejects the idea of accepting French occupation:

Struck by this unbelievable fact, I assembled a large number of fleeing soldiers, the ill-fated and the women and took them to Constantine-a long story. I gave them all sufficient provisions and the soldiers, their pay ... And as soon as the scholars, noblemen, and sheikhs of the town learned what had happened to the Dey of Algiers, they renewed their oath of allegiance and endowed me with the title of Pasha, just as they described it in their presentation to the Sublime Porte. I could only but subscribe to it. I raised new troops and cavalrymen that cost me all my inheritance, since, according to divine law and to maintain too the obedience and submission of the people, it was impossible for me to increase the tithe. The enemy, in its letters that it circulated, announced to the population that it had come to remove injustice; I cannot accept what it proposes to do. ${ }^{5}$

In November 1836, Ahmed Bey repels the first siege of Constantine by the soldiers of Maréchal Clauzel and, fortified by this spectacular victory, opposes Abd-el-Kader who, by finally signing the Treaty of Tafna with France in May 1837, enables the latter to turn against the Bey of Constantine and to overthrow him a few months later. With the defeat of the town in 1838, Ahmed, who had not accepted the French proposals and continued to fight, was still looking to the Sublime Porte for approval, as can be seen in a letter of January 16 to the Ministry of Defense in Istanbul, the follow-up to another shorter letter, sent in October 1837:

If you hope and intend to conserve the continuity of Islam, save this country from French hands, help your faithful servant, for you are our Protector before God. As the Sultan looks after his people, you must surely come to our succor as quickly as possible, otherwise the population will abandon us. Now, it would seem that our Lordship is neglecting his servant, which would mean that our Sultan, the great Lord, is in anger against me; for, if he were not, it would not be reasona-

5 Abdeljelil Temimi, “Trois lettres de Hadj Ahmed Bey de Constantine à la Sublime Porte," Revue de l’Occident musulman et de la Méditerranée, no. 3 (1967): 133-52. 
ble to leave this province as prey for the French, without helping the Muslims; and since we have not received the slightest help, the French are sure to carry out their hopes. And if it comes to light that you had not helped the Muslim religion, you will undoubtedly be held responsible. We entreat you to forgive us our daring and impolite but truthful words, for our affront is justifiable ... Since you are the Minister of Defense on land and sea, we place all our hopes in you to find a remedy to our misfortune, for nothing will stop the French from occupying the whole country, and, subjected to their plundering, we shall be reduced to slavery.

The accounts after the French conquest ${ }^{6}$ have stressed the cruelty of the personage rather than his cosmopolitanism; these judgements-serving French propaganda, endlessly denouncing the despotism of the Turks and pretending to bring it to an end to justify the invasion ${ }^{7}$-accord also with the Orientalists and their Oriental-tyrant clichés; yet they are, to a great extent, disproved by the facts. ${ }^{8}$ Not only do the French authors-mainly Laurent-Charles Féraud-say nothing about the culture of the personage, but they make a point of stressing the expropriations he had to carry out to build his palace: they mask all the courage and humanity he showed in the difficult circumstances-notably at the fall of Algiers-that are qualities that Hamdan Khodja, on the contrary, puts forward.

The construction of the palace is intimately linked to the life of the Bey; wishing to leave the traditional dwelling of Dar el Bey, a place that was to him marred by too many depositions of beys, he chooses Dar Oum Noum - where the house he was born in used to be-to begin building a new palace in 1826. With the stress of events, it is to be built in two phases: the first sees the elevation of a building around the Courtyard of the Orange Grove, laid out on the site of a former Janissary arsenal. This first arrangement has the diwan (chief administration office) in the center. Then, after 1830, the palace is extended and includes the harem, the patio, and the Courtyard

6 See Wendelin Schlosser, Reisen in Brasilien und Algier oder Lebensschicksale Wendelin Schlossers, zuletzt gewesenen Bombaschia des Achmed Bey von Constantine (Erfurt: Hennings u. Hopf in Komm, 1839); Jean-Pierre Bonnafont, Réflexions sur l'Algérie, particulièrement sur la province de Constantine, sur l'origine de cette ville et les beys qui y ont régné depuis l'an de l'égire (sic) 1133 (1710) jusqu'en 1253 (1837) (Paris: Ledoyen, 1846); Laurent-Charles Féraud, "Monographie du Palais du Bey à Constantine," in Recueil des Notices et Mémoires de la Société archéologique de la Province de Constantine, vol.11 (1867): 2-96. See also Guy de Maupassant about Ahmed Bey and his palace: "t would need a volume to give an account of the ferocities, the corruption, all the infamy of the one who built it with the precious materials taken from the elegant houses of the town and its surrounding areas." Lettres d'Afrique (Algérie, Tunisie), ed. Michèle Salinas ([orig. ed., Le Gaulois, 1881]; Paris: La Boîte à documents, 1997).

7 See what a person of letters, Hamdane Ben Othman Khodja (1773-1842), witness to the first years of the conquest, said about this in Khodja, Aperçu historique et statistique sur la Régence d'Alger.

8 Among the Arabian authors, only Salah El Antri-whose father sided with France and who was himself the first khodja of the Arab Bureau in Constantine-gives a negative portrait of Ahmed Bey; the book was edited by Captain Boissonet, head of the Arab Bureau in Constantine. 
of the Palm Grove. The presence of courtyard gardens makes it a unique example in Algeria for an urban palace; perhaps it was inspired by the walled gardens of the elegant dwellings on the outskirts of Algiers (the so-called Algiers Fahs), or by the abode of Salah Bey. Apart from this particularity, the palace has much in common with the Ottoman palaces of the same era: an entrance hall (sqifa) leads indoors to the twenty-seven apartments arranged around a central space opening onto galleries. In this setting, two-hundred and forty-five elegant marble columns are the heralds of the palace. These columns are somewhat evocative of those at the Dar Aziza Palace in Algiers with their Solomonic or octagonal drums supporting the horseshoe arches. As to the glazed tiling from Italy, Spain, the Netherlands, Tunisia, and Turkey, it is yet another feature in common with the Algerian Ottoman palaces and rivals them in sumptuousness.

At the beginning of 1837, the palace caught the attention of the new French occupier with its harmony and refinement: the army took it over at once to transform it into the officers' general headquarters and barracks and did not leave it until 1962. Even though the whole complex registered was belatedly listed as a protected building in 1934, it was nonetheless tremendously altered by this occupation. Napoleon III's visit to Constantine, in 1865, led to intensive transformations. On this occasion, and then over the following years, murals were sometimes destroyed, sometimes covered by new compositions of rather graceless floral medallions, and sometimes spoiled by additions-in particular with motifs of red, white, and blue garlands. Moreover, outside, many of its surrounding buildings were destroyed to create new streets or modify old ones, and in 1838 a place d'armes (military courtyard) was opened with the aim of monumentalizing a quarter that had formerly been an intrinsic part of a dense urban landscape. In short, the palace as it stands today is not the palace conceived by Ahmed Bey: the private apartments of his family, in particular, are no longer to be seen.

Following independence, between 1962 and 1969, the Algerian army took over from the French army, then transferred the whole property to the Constantine town council. Restored by the Ministry of Culture after 1982, the palace was listed as a historical monument and has been managed by the National Heritage since 2008. In 2010, the National Museum of Arts and Popular Traditions was housed there.

To these three periods-beylical, colonial, and national-three major tonalities can be affixed that, in each instance, confer their identity to the Ahmed Bey Palace: the deliberate stylistic mélange at the time of its construction, its heterogeneity, vacillating between destruction and conservation at the time of French occupation, and, finally, the quest for authenticity after independence. 


\section{Cultural Crossings: An Ongoing Identity during the Beylical Period}

As much as can be judged today, the construction of the palace was steered so as to pursue diversity in order to reach something that was deliberately a mixing of European elements (especially due to imported faience earthenware as can be seen in the Algiers palaces) and Oriental elements (marquetry decoration, balustrades, wall paintings). In the Bey palace, these intersections become systematic in character: Hispano-Maghrebi, Ottoman-Turkish, and European influences are intertwined, as much in their materials and techniques as in their motifs, so as to leave their respective origins clearly visible while the interplay provokes an effect of wonderment at the resulting harmonious differences.

Some of the two hundred and forty-five marble columns ${ }^{9}$ have supposedly comeaccording to Laurent-Charles Féraud-from "several beautiful Algiers townhouses,"10 and been manufactured in Annaba or Tunis, from marble of Italian, Algerian, and Greek origin. Some are undoubtedly also of Italian make since the Genovese architect Schiaffino had the responsibility of importing the marble columns, with every possible care taken for their transport. These columns have capitals distributed in no apparent order, with plant motifs (e.g., leaves or grapes of Ottoman inspiration), simple truncated cones with a croissant relief, or capitals of Corinthian, Tuscan, or

9 Two hundred and sixty-six, according to Laurent-Charles Féraud in 1867 (Féraud, Monographie du Palais du Bey, 19).

10 Féraud, Monographie du Palais du Bey, 15.

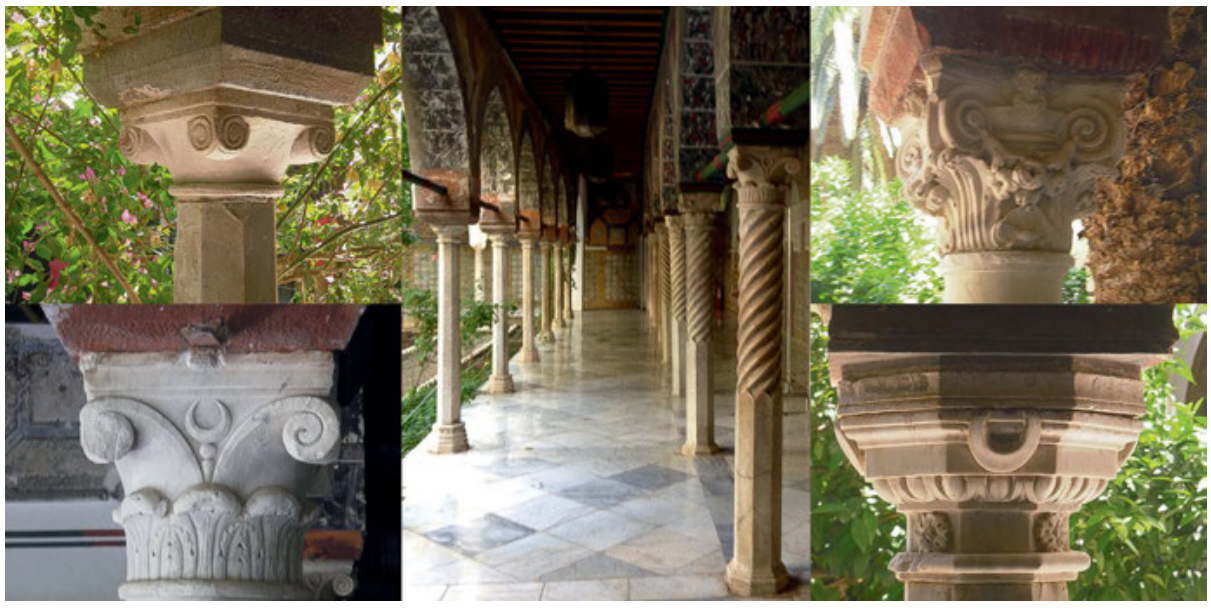

Fig. 1: Ahmed Bey Palace, Constantine (Algeria), 1830-1835. Examples of marble capitals. 
Fig. 2: Wooden door with one leaf, Constantine woodwork, Ahmed Bey Palace, Constantine, 1830-1835.

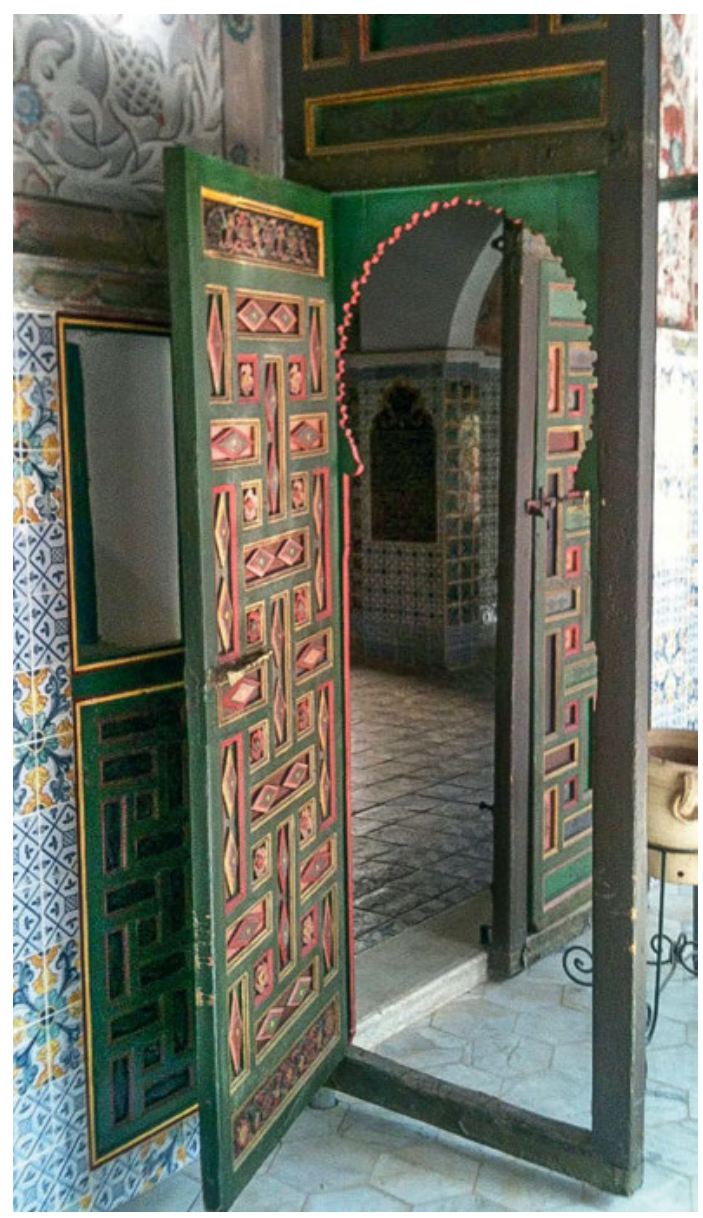

Greco-Byzantine influence (fig. 1). The base of the columns are likewise sometimes simply nonexistent, sometimes decorated, or sometimes not at all, in varied heights and proportions; ${ }^{11}$ and as for the doors, the woodwork is typically Maghrebi (fig. 2), while their marble frames adopt either Italian or Andalusian-Maghrebi forms.

One of the most spectacular aspects of the decoration is the ceramic tiling: over one-thousand six-hundred-square meters of faience tiles (zelaidj) covering the lower walls and creating in situ an encyclopedia of Mediterranean and European mural ceramics at the end of the eighteenth century and beginning of the nineteenth (fig. 3 ).

11 Ibid., 19 ("The arches are generally ribbed and mounted on monolithic white marble columns, unequal in height and of great diversity in form. Some are svelte and elegant, others stocky and massive; different forms are to be seen: round, Solomonic, and octagonal.”) 


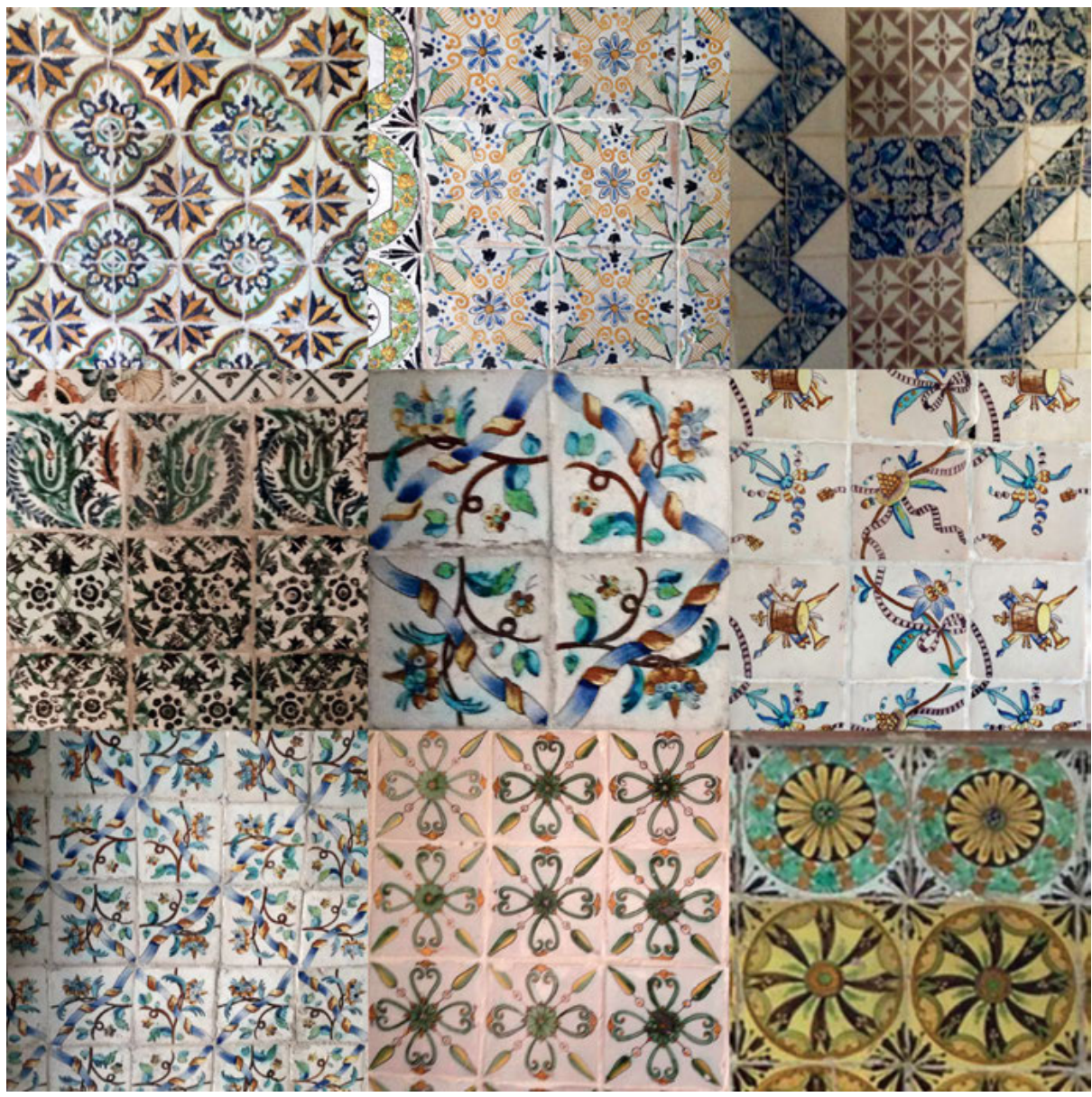

Fig. 3: Ahmed Bey Palace, Constantine (Algeria), 1830-1835. Examples of panels of tiling in the Harem Courtyard gallery.

Large tiles with vegetal and floral decoration (scrollwork, ribbons, latticework, etc.) intermix with geometrical motifs (stars and interlocking circles, interlacing, arabesques, etc.) and figurative ornamental compositions (maritime motifs, birds, imaginary people); Dutch examples sit alongside Andalusian-Maghrebi and "Damascene" styles, in, then again, no apparent order.

If, on the whole, these tiles can be considered an element of Occidentalism, the woodwork (doors, balustrades, windows, cupboards), on the other hand, forms a clearly Ottoman-Maghrebi element. The doors punctuate the space with their decor of geometric or arabesque inspiration and their bright polychromatic colors (yellows, greens, and reds). The adornment of the windows differs slightly: on the outside, their wooden shutters have been dotted with a geometric design; inside, they are some- 


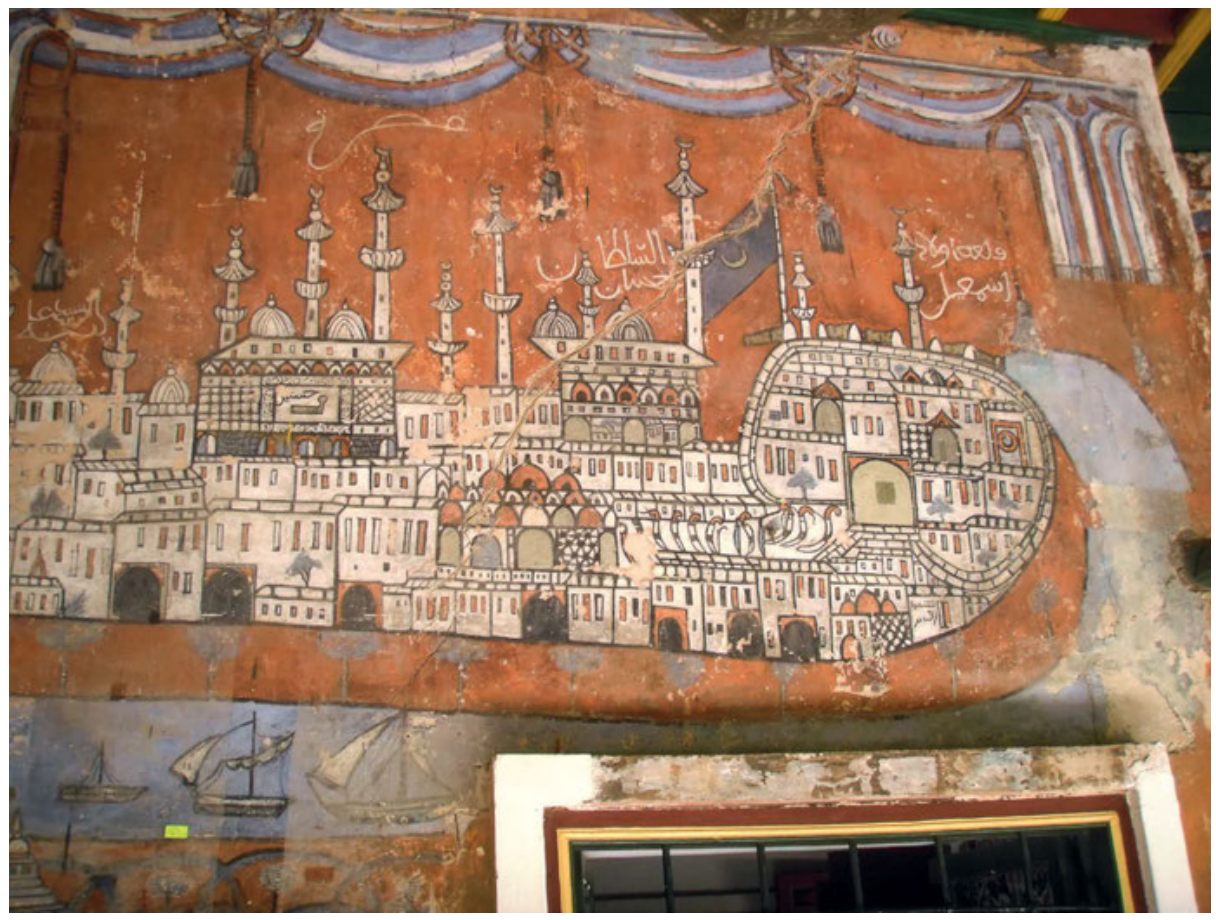

Fig. 4: View of Cairo, Ahmed Bey Palace, Constantine (Algeria), wall painting from the west corridor of the ground floor of the courtyard of the Palm Grove, ca. 1830, and repainted in the 1860s.

times fitted with glass mirrors, the rule being that interior ornamentation remains the most elaborate. The balustrades, in harmony with the colors of the doors had their place between the columns: each element consisting of two levels of balusters in turned wood, separated in the middle by a grating. The effect of all this carpentry contributes to giving a strong local identity to the palace.

The wall paintings on the top half of the walls complete this overall effect with a great number of non-figurative designs as well as a cycle of narrative compositions retracing the travels of the Bey (fig. 4), composed between 1830 and 1835 by El Hadj Yousef, an Algiers painter trained in Egypt. ${ }^{12}$ It is on these murals that the colonial interventions are the most extensive, often to the point of complete repainting-trompe-l'œil, floral medallions, etc.-making it difficult to appreciate fully their original effect. In addition to this, pre-Beylical figurative motifs-with their naïve narrative style in manuscript painting-have been revealed under the later overpainting

12 His name is mentioned in 1877 by Laurent-Charles Féraud in the rewriting of his 1867 monograph of the palace: "Visite au palais de Constantine," Le Tour du monde, vol. XXXIII, no. 849 (Paris, 1877), 254. 
during recent restoration work, in one of the outhouses of an old Constantine residence (annexed to the original palace at the time of its construction).

This interior decor, marrying thus the most diverse materials of far-flung geographical origin, is nevertheless strongly structured by the clarity of the spatial organization that balances out the ornate dissimilarity of the decoration. Practically devoid of any openings, the distinct inside-outside aspect and the relatively modest proportions of the interior intensify one's immediate apprehension of the dynamic articulation between the three courtyard gardens on the first floor communicating with the "Chamber of the Princess" and its open antechamber-the veritable hub of the three spaces with their surrounding arcades. This tripartite geometry itself generates movement; its simplicity corresponds, besides, to a no less distinct distribution of functions between the public spaces near the entrance and the private spaces at the rear, with the Harem Courtyard right at the back.

This alliance of clarity and diversity represents what could be characterized as an aesthetics of hybridity, first recognized by Laurent-Charles Féraud in 1867 for its visual efficacy, even if-through already deep-rooted colonial prejudice-he attributes it to a "freak of chance" rather than to an artistic and cultural intention in line with the origins, upbringing, and personal sensitivity of Ahmed Bey:

It is these multiple sources that have engendered the disparate look in the adornment of the palace ... But if all these details are not irreproachable as to taste and harmony, one cannot help seeing in them a character-a real fluke-that composes their veritable originality ... The capitals show an amalgam of the most disparate and incoherent styles ... The side walls are covered, up to eye-level, with multicolored faience tiles of all origins, forming-in their arrangement-intertwining floral patterns or very fine-looking mosaics. I am convinced that an antiquarian would find some very interesting samples of early hand-made glazed tiles in the palace and could do interesting research on the art of ceramics. ${ }^{13}$

Can one talk of Occidentalism with reference to this Beylical phase of the palace the way one talks of Orientalism with reference to European exotic pastiche in the spirit of John Nash's 1822 Royal Pavilion in Brighton, among many other examples at the turn of eighteenth and nineteenth century? In fact, during the same epoch, Occidentalism too is vaunted in Ottoman palatial architecture and apparently Ahmed Bey was an admirer of it: the Dolmabahçe Palace, for example, built in Istanbul by the architect of Armenian origin, Garabet Amira Balyan between 1842 and 1856, is a particularly spectacular late illustration of this, with its Italian neo-Baroque style. Be they "Occidentalist" or "Orientalist," these edifices of the first half of the nineteenth century have one thing in common: they transport the inhabitant or the visitor into another world-the other as aesthetic horizon. This otherness is not only based on a deliberate disparity with the cultural identity of the patron but on a fundamental distancing

13 Féraud, Monographie du Palais du Bey, 15, 18, 20. 
as opposed to experienced reality. A parallel world, a picture-book world opens its doors, the phantasmagorical coherence of which sets out to melt reality into virtual.

Within the Ahmed Bey palace walls, on the other hand, the Ottoman-Maghrebi local identity is strongly highlighted, while at the same time combined with a conscious Occidentalist exoticism. In this way, the architecture is closely in tune with immediate reality, be it intimately personal, considering the sovereign's mixed cultural origins and his Mediterranean travels, or collective, in the context of the cosmopolitan culture of Algeria vested by the input of the Andalusians and Turks, living side by side in a town like Constantine against a backdrop of Kabylian, Arab, and Jewish elements.

One cannot talk of eclecticism either, in the way Western Europe developed it, at the same period, by juxtaposing clearly identifiable historic styles-of antiquity, Byzantine, Mediaeval, Renaissance, Baroque, etc.-in one and the same monument or urban space. Eclecticism cannot, indeed, be separated from historicism: with a more or less scholarly recourse to bygone styles, it attempts to demonstrate the superposition of times and replaces the geographical otherness that is Orientalism (or, symmetrically, Occidentalism) with some temporal otherness. Now, the architectural and decorative poetics embraced by the Ahmed Bey Palace is firmly rooted in the present: just as-in the palace-the here prevails over the elsewhere, the present prevails over the past. That is to say, this present is a fundamentally political one: faced with the threat of the French, everything happens as if it were a question of continuing to assert the very forms of eighteenth and early nineteenth-century prosperous Algeria, to stage an Ottoman Maghreb, proud of its capacity to interweave the different cultures of the Mediterranean. In its ornamental profusion, both symbolic and decorative ambition seem to go hand in hand: political thought and the harmony of existential practice have to show mutual support.

This coherence is due mainly to the supervision of two artists, El Hadj El Djabri, master stoneworker, native of Constantine, and El Khettabi, of Kabylian origin. Moreover, even if a certain number of elements are imports, they have been reworked, transformed, and set up in situ by teams of artisans, where the local savoir-faire is omnipresent and palpable, whatever the cultural origin of these creators to whom the edifice owes its paradoxical aesthetic unity or, say, its harmony. Personifying-in the strictest sense of the word-a Mediterranean multiculturalism, the diverse stylistic and material references have undergone a process of digestion rather than fusion, ensuring the dynamics of their presentation. This integration of foreign elementsbe it a material, practical, or symbolic process of local appropriation-corresponds to what could be called boundary building; ${ }^{14}$ more than anything, it is in harmony with the notion of hybridity, the semantics of which is evolving at precisely the same

14 See Exogenèses: Objets frontière dans l'art européen XVI siècle, ed. Sabine du Crest (Paris: De Boccard, 2018). 
time-in the 1820s-from an etymology that stresses the organic character of forms comparable to those of "mixed blood" living organisms. ${ }^{15}$ If this etymology holds true, artistic hybridity is in complete contradiction with exoticism and historicism: its compass is life in the present, the here and now, and not that of an imaginary elsewhere. In contrast to the phantasmatic coherence of world-images, it deliberately gives right of way to differences, borderline disorder even, and never ceases playing with unstable stabilities.

In the Ahmed Bey Palace, the historical circumstances-and perhaps the intensity of the personal wish of the patron-have been the successful factors in this charade. It is not just a question of a subjective early twenty-first century judgment: the aesthetic success of the venture is corroborated right from the start by the reactions of the French occupiers who seem to have been all the more fascinated that, precisely, this grace of a vivid composite building was no longer lived against the backdrop of the new colonial environment, and became inexorably exotic, as if the Algerian past were a Paradise Lost.

\section{Colonial Heterogeneity: A Split Identity}

At the time of the defeat of Algeria in the 1830s, the patrimonialization of the past was a heated debate in France: legislation for the protection of historical monuments was established in answer to the acute consciousness of the destruction inherent to the industrial revolution and the economic imperatives of capitalism. The rising cult of authenticity is evidence of an artistic and cultural melancholy counterbalancing the faith in techno-scientific "progress." An obsession for the past, embedded as it is in the present, challenges the spontaneous preference to the latter.

At their arrival in Algeria, the French cannot therefore avoid the question of the conservation of local heritage. They have to choose immediately between destruction or patrimonialization; it is common knowledge that they chose-massively-destruction, in spite of a few timidly critical voices, such as that of the architect Amable Ravoisié, after his "scientific exploration” of Algeria between 1840 and 1842 (fig. 5):

Instructions given for a long time now by the superior orders demand the seizure of all the ancient ruins to claim ownership of them, as far as possible to new ends, or demolish them to use the materials to construct other buildings for the different public services. As this last choice was

15 "Hybrid" may come from the Latin ibrida, qualifying a mixed-blood being (originally the result of the cross-breeding of a boar and sow). If the adjective first appears in France in 1596, the verb "hybridize" as well as the nouns "hybridity" and "hybridization" appear around 1825 in French. For a critical approach of the use of the notion of hybridity in the context of social sciences, see in particular Stephen W. Silliman, "A Requiem for Hybridity? The Problem with Frankensteins, Purées, and Mules," Journal of Social Archaeology 15, no. 3 (October 2015): 277-98. 


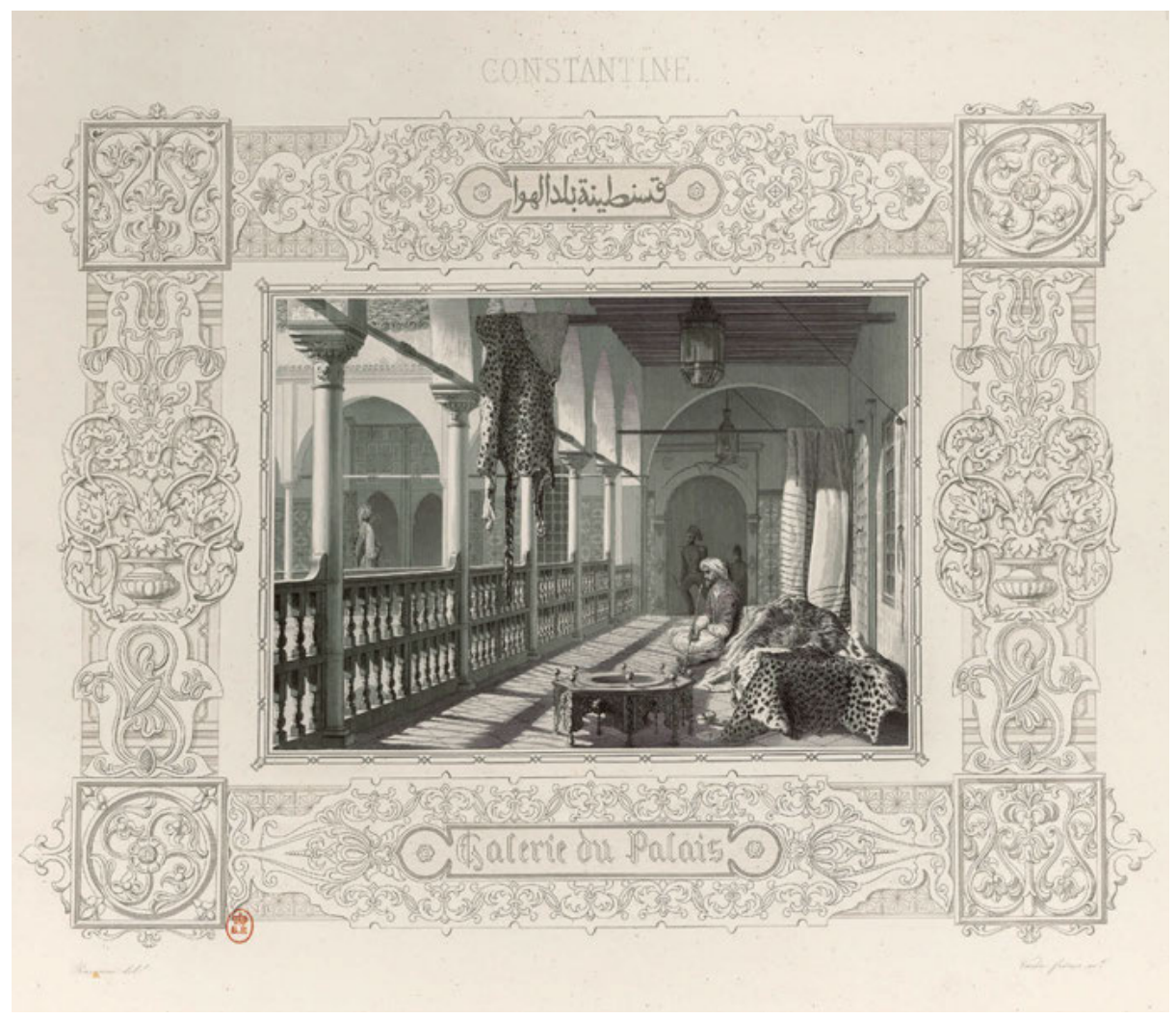

Fig. 5: Amable Ravoisié, Exploration scientifique de l'Algérie pendant les années 1840, 1841, 1842: Beaux-arts, architecture et sculpture, vol.1, Constantine (Paris: Didot, 1846), pl. 20, "Palace built by Achmed, the last Bey de Constantine."

unfortunately the one that was the most generally adopted, the scientific commission thought its first duty was to look to the ruins that the presence of our troops and the demands of the conquest threatened with imminent devastation. ${ }^{16}$

Then the researcher contents himself with carrying out an inventory in extremis "to evaluate the situation and the character of the barbaresque art, before these edifices, caught up in the general catastrophe, suffer the inevitable consequences of the revolution that is waging in this country, and which is deeply changing its mores and institutions." 17

16 Amable Ravoisié, "Exploration scientifique de l'Algérie pendant les années 1840, 1841, 1842," Beaux-arts, architecture et sculpture, vol.1 (Paris: Didot, 1846): III-IV.

17 Ibid., IV. 


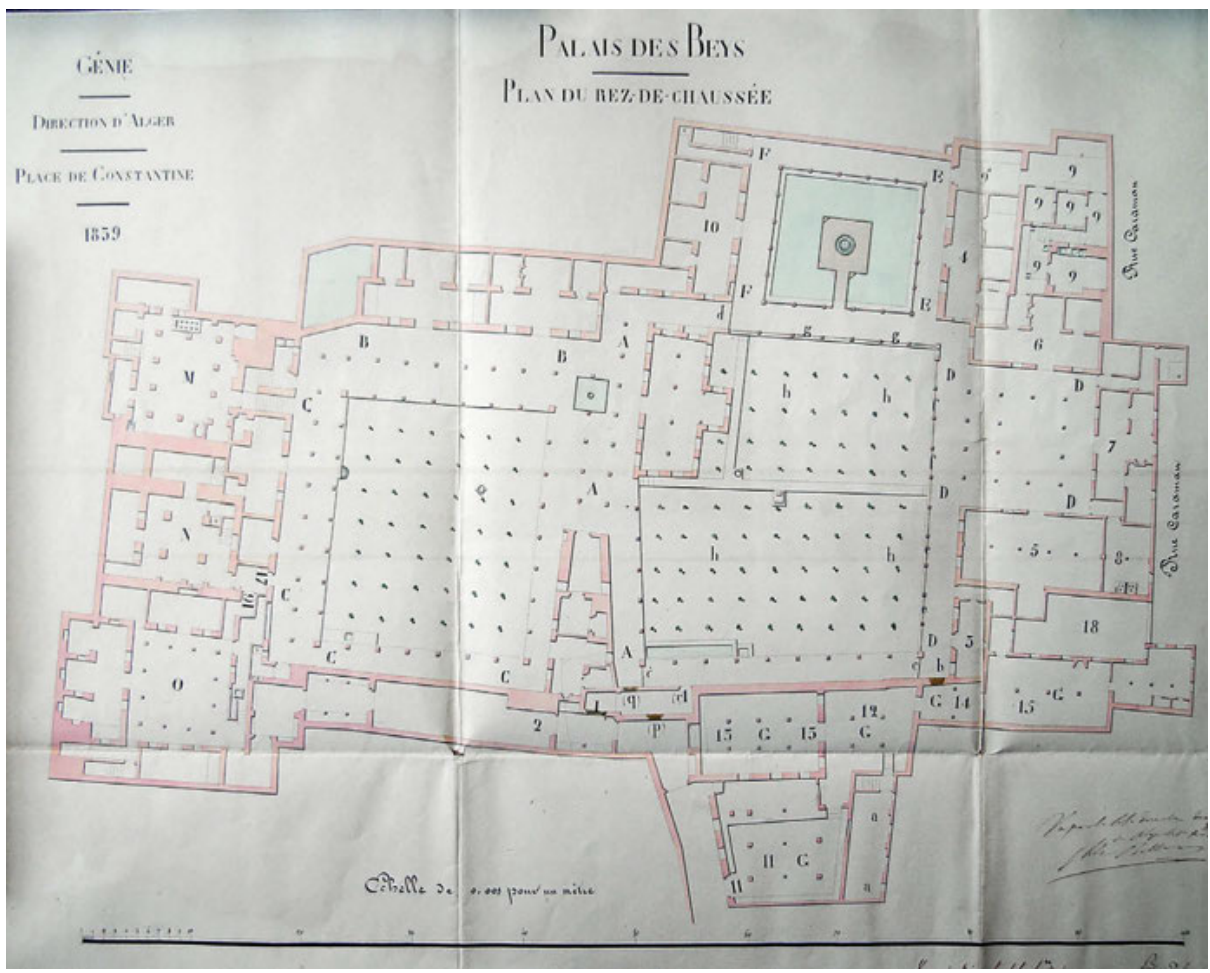

Fig. 6: [Military] Engineering Service, Head Office in Algiers, Place de Constantine, "Palace of the Beys. Ground Floor Plan," 1839, ink and watercolor on paper, Château de Vincennes, Archives of the Historical Service of the Ministry of Defense.

In this context, the fate reserved for the Ahmed Bey Palace is an intermediary one: taken over by the army, its condition has seriously deteriorated, but is however, partly salvaged and even restored so that three types of area coexist: state rooms, administration offices, and lodgings, the former being more or less preserved while the latter two are greatly altered. Photographs at the time and present-day remains enable an estimation of the impression of the resulting heterogeneity, symptom of the Occidental identity crisis during colonial rule; its belated inscription on the register of historical monuments, in 1934, changes practically nothing.

Indications that the building was subject to particular respect are not lacking. Although it is practically contemporary, the patrimonial aura that it has rests both on its extraordinary aesthetic quality and on a desire to let a few monuments testify to a bygone age, in a time marked-for the French-by the hubris of the tabula rasa. That is why it is relatively spared of the demolitions and radical reconfigurations that Constantine suffers in the very early days after its defeat, from 1837 on. It is even routinely consolidated, especially after the damage caused by the 1856 earthquake. It is also 
the object of technical inventories and descriptions that the French army is the first to carry out, since the building is inexistent at the time of the first travelers to Constantine, toward the end of the eighteenth century. ${ }^{18}$ From 1837 on, the Military Engineering Corps establishes the town street map, with the palace in the center; floor plans of the palace itself are drawn up in 1839 (fig. 6).

Then Ravoisié visits the town in April 1840 and writes about it in the first monograph of his Exploration scientifique de l'Algérie. In spite of his insistence on antique monuments, he devotes two plates-of twenty-four-to the "Palace built by Achmed, the last Bey of Constantine" (fig. 7), not without voicing aesthetic reservations that, in themselves, reveal the shortcomings of academic criteria at the time as to the composite character of the building:

This building, not lacking in a certain elegance, is however, from an artistic point of view, not the most remarkable, by a long chalk, of all those in Constantine; but, in size, it is certainly the biggest of all the dwelling houses ... It was built in such a hurry that every day something is done to consolidate it. ${ }^{19}$

It is Laurent-Charles Féraud, an Arabist, interpreter for the French African army, painter, and secretary of the "Société archéologique de la province de Constantine,"20 who writes, in 1867, the first systematic analysis of the monument, in a monograph of about one hundred pages; ${ }^{21}$ it is partly re-edited in 1877, as a sort of "tourist" article, in the magazine Le Tour $d u$ Monde $e^{22}$ and thus contributes to spread the fame of the monument beyond the sole Algerian colonial class. This time, praise is much more effusive for "one of the most beautiful and interesting Arabian monuments that it is possible to come across in Algeria.”23 Its exceptional quality, according to the author, justifies the appeal for an official patrimonialization, in spite of its quasi-contemporaneity:

This building, finished only yesterday, presents so many elements suitable for getting to know the floor plans and the details of Algerian architecture, as to deserve to become a listed historical monument. $^{24}$

This exceptional desire of listing a chronologically-recent historical monument (although rejected by force in the past due to colonial rupture) is, however, associated

18 See Ernest Mercier, Histoire de Constantine (Constantine: J. Marle and F. Biron, 1903), 245-47 esp. ("Détails du voyageur Peyssonnel ... complétés par ceux de Shaw").

19 Ravoisié, Exploration scientifique, pl. 21, "Petite cour du Palais."

20 See Bernard Merlin, Laurent-Charles Féraud, peintre et témoin de la conquête de l'Algérie (Paris: Monelle Hayot, 2010).

21 Ibid., n. 4.

22 Ibid., n. 8.

23 Féraud, Monographie du Palais du Bey, 2.

24 Ibid., 95. 


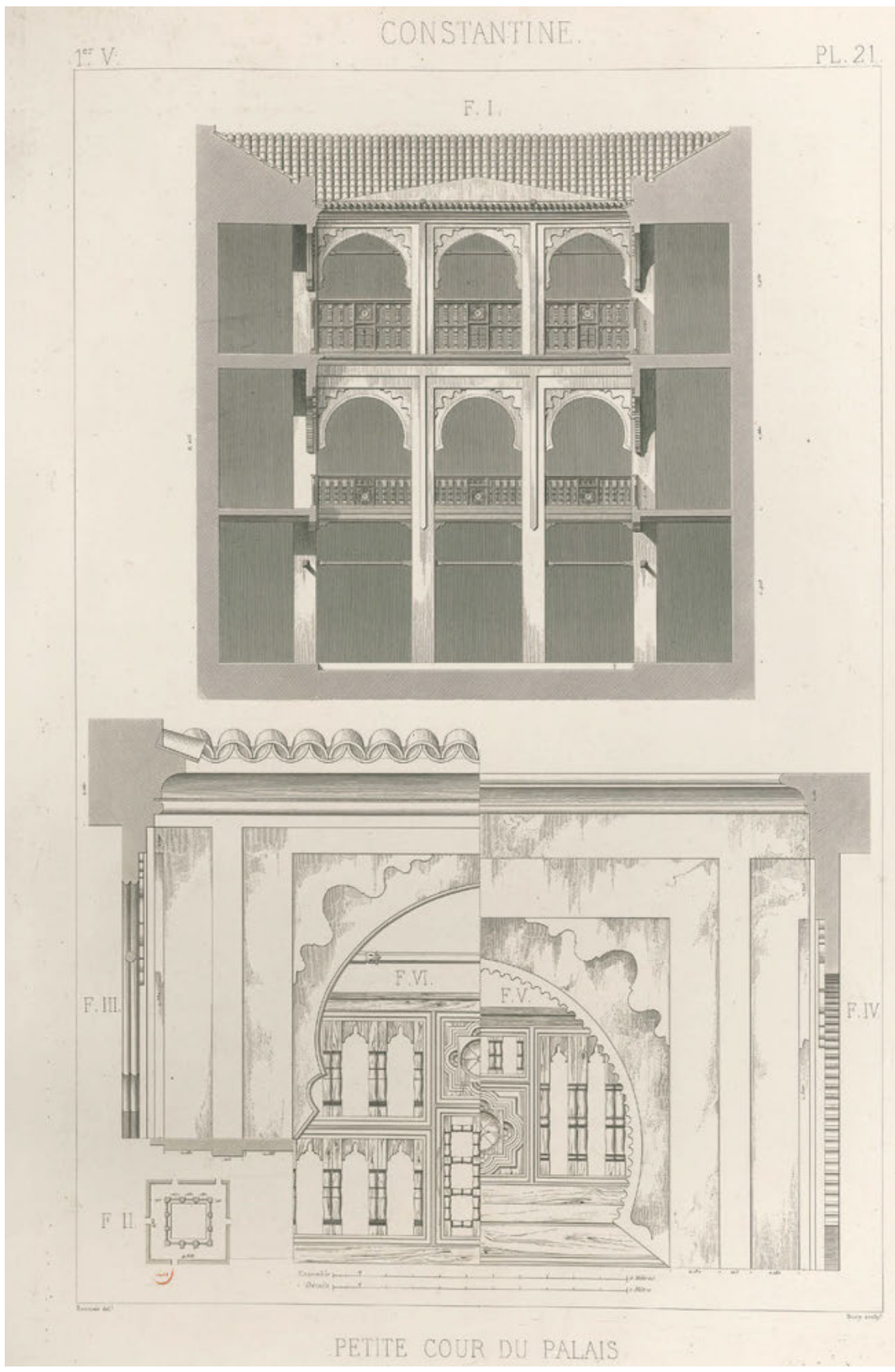

Fig. 7: Amable Ravoisié, Exploration scientifique de l'Algérie pendant les années 1840, 1841, 1842: Beaux-arts, architecture et sculpture, vol.1, Constantine (Paris: Didot, 1846), pl. 21, "The Palace Small Courtyard." 
with inverse procedures of destruction, or, at least, of violent appropriation, involving some forms of vandalism. The razing of a great number of the surrounding buildings also affects the adjoining houses of the palace, especially the house of the Bey's mother, while a new structure is added to the northwest wing. Doors and windows are opened in the outside and inside walls, the openings of the top gallery between the two courtyards, the Palm Grove and the Orange Grove courtyards, are paned in colored glass; the water-parterre of the Harem Courtyard is destroyed and the Orange Grove Courtyard completely changed-at the time of Napoleon III's visit in 1865-by the planting of two Lebanese cedars, the addition of fountains, plus a spiral staircase in one of the corners for access to the top gallery. Inside, wooden balustrades are removed and dividing walls are built to create more rooms, often enhanced with typically European moldings, as can be seen in the restoration report drawn up by a Polish team in 1984-85: "In the colonial period of the second half of the nineteenth century, these (original) interiors were divided into several smaller rooms, which has completely modified the original layout."25

But it is mainly in the painted decoration that the interventions shock the most, visually, as if the new occupier wishes to affirm his superiority of technique, that is to say, painting, considered as one of the fine arts and therefore an Occidental prerogative. The overpainting abides by different registers, resulting in violently discordant effects: some, painted by two local painters in $1860,{ }^{26}$ bring out the original Ottoman motifs; some are painted over with, notably, a series of festoons of red, white, and blue garlands along the top of the painted panels; and finally, others are covered with floral-like compositions in medallions. There again, the restoration report of $1984-85$ is articulate:

The painted decoration, dating from the period of the palace's construction has seriously deteriorated, having been restored in the second half of the nineteenth century and repainted several times since. The composition of the outside decor of the Orange Grove Courtyard on the first floor and the Belvedere has been completely transformed. In the other cases, the exterior paintings have partly revived the decoration of the Bey's time. ${ }^{27}$

In total, three periods of intervention can be found, first in the 1830s, then between 1860 and 1865 , and lastly during a new campaign, not so well dated, toward the end

25 Palais d'Ahmed Bey à Constantine: Expertise des peintures murales, ed. Jacek Radolowicz, vol.1 (type-written paper conserved in the town archives of Constantine).

26 See Féraud, Monographie du Palais du Bey, 85: "In 1860, all these paintings were already considerably damaged because of damp. It would have been imprudent to entrust their restoration to European workers, who, inevitably, would have wanted to improve them and in so doing even rob them of their original distinctive character. We had therefore the presence of mind to entrust this task to two locals whose public renown told us they had contributed to the first enhancement of the palace: the aforesaid Barar and Si Ioussef."

27 Palais d'Ahmed Bey à Constantine, n.p. 


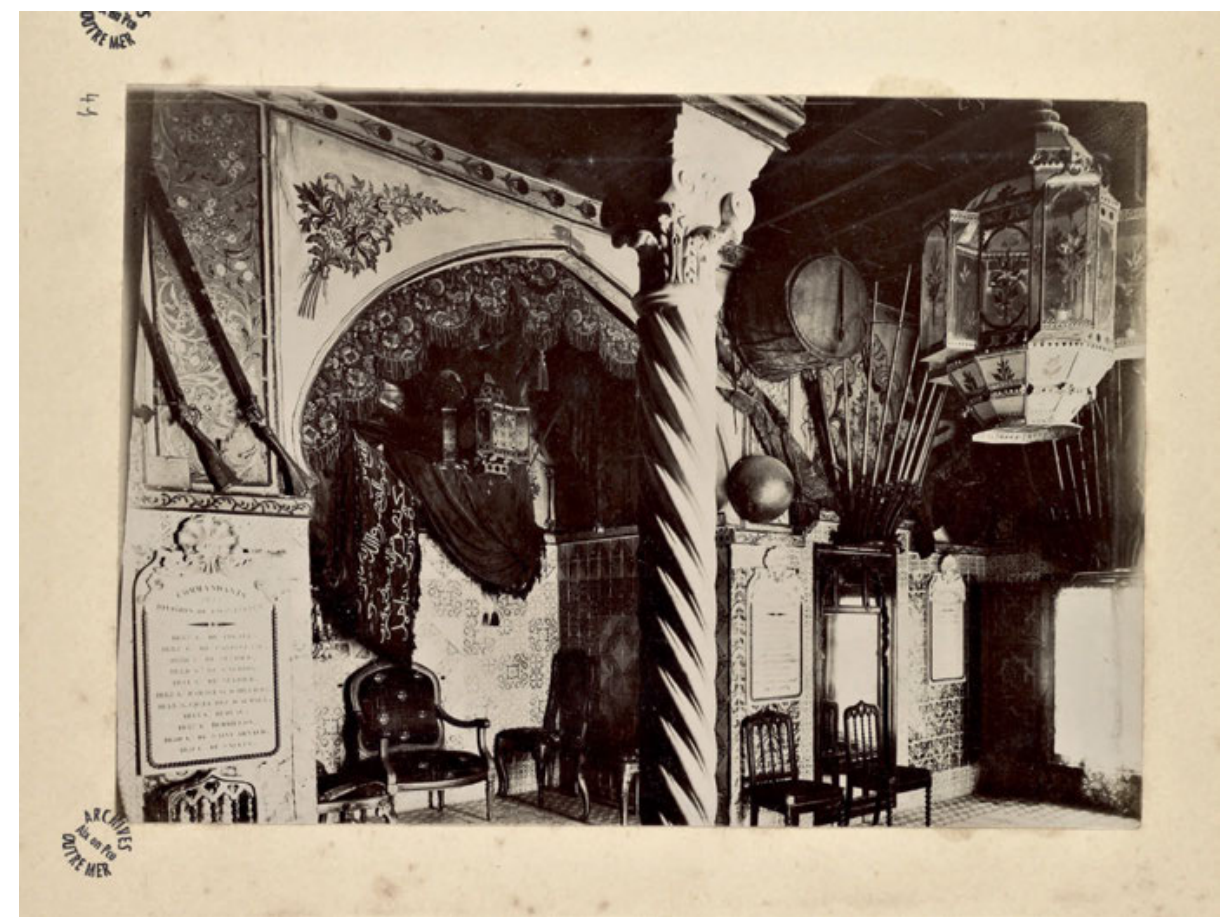

Fig. 8: “Trophy Room," former Chamber of the Princess, daughter of the Bey, Palace Ahmed Bey, Constantine, state, ca. 1860-1870, ANOM, FR ANOM 8Fi444/41.

of the nineteenth century or the beginning of the twentieth century. Of these periods, it is the first one that seems to be the most fragmentary, as is probably the case in "the polychromes of the galleries on the ground floor and on the first floor that were $100 \%$ repainted." 28 Added to the iconographic and chromatic differences between the layers of paint is the fact that from a technical point of view, "they are not at all homogenous as far as method is concerned," 29 which increases the visual impression of discordance.

The new uses to which the spaces of the palace are allotted are not any less discordant and demonstrate the dysfunction in the colonial procedures of appropriation, wavering between a desire of authentic conservation and a desire to assert supremacy. Thus, a museum space, known as the "Trophy Room” ("Salle des Trophées," fig. 8), is set up in the "Chamber of the Princess," the bedroom of the Bey's daughter and the hub of the whole palace, by General MacMahon, who became commander of the Constantine division in March 1852, after having participated in the victorious siege of 1837 :

28 Ibid.

29 Ibid. 


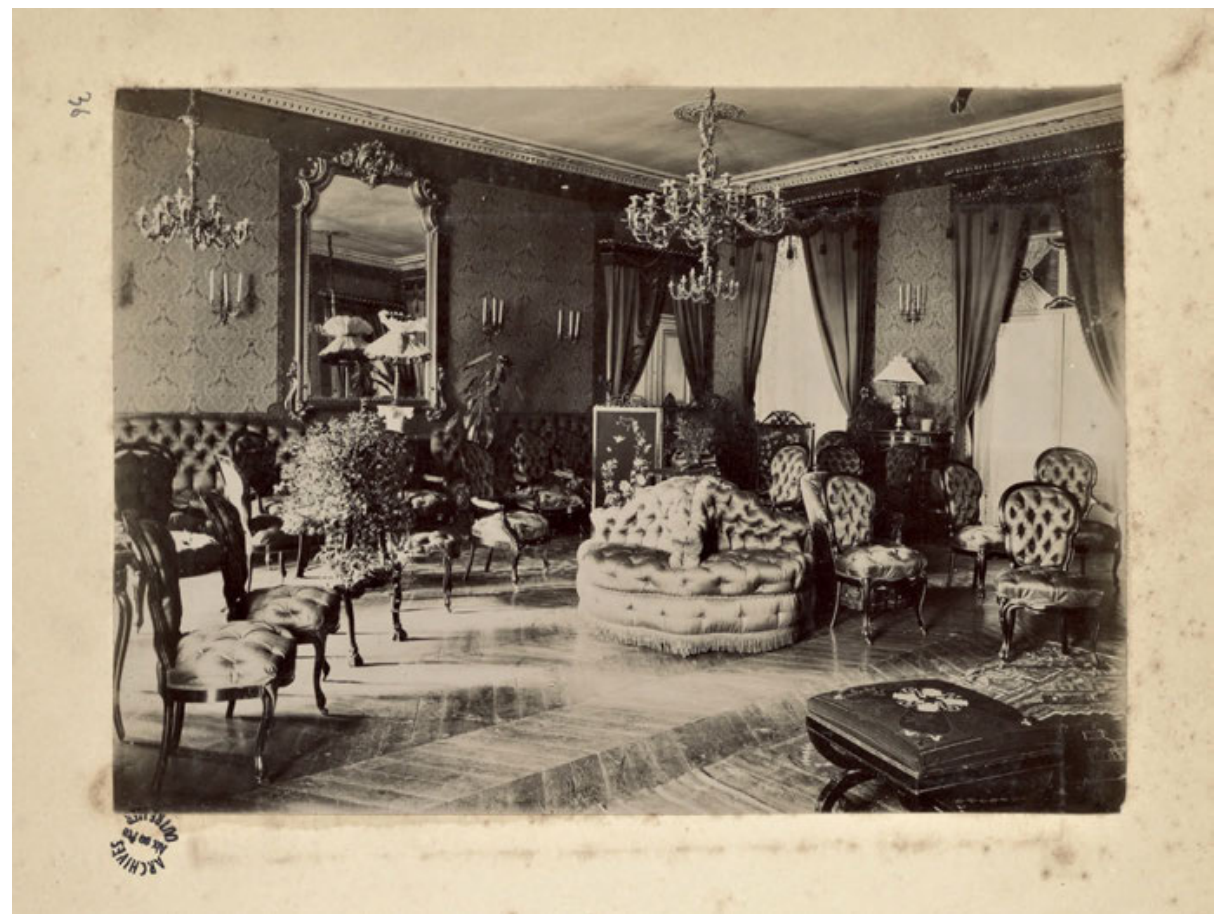

Fig. 9: Drawing room in the apartments of the commander of the Division de Constantine, Ahmed Bey Palace, Constantine, ca. 1860-1870, ANOM, FR 8Fi444/36.

What is most intriguing about the room we are visiting, is, without a doubt, the collection of trophy weapons and flags adorning its walls. They are, in a way, authentic archives perpetuating the memory of feats of arms and expeditions carried out by our troops over all the regions of the province of Constantine. We owe the initiative of this happy and useful innovation to General MacMahon; it has been continued since, by his successors. Rifles, sabers, pistols, muskets, and clubs, in the most diverse forms, make up these trophies ... The Touggourt trophy contains, besides weapons, a curious collection of musical instruments. ${ }^{30}$

If the photographs conserved are to be believed, the room is disfigured by inscriptions and objects that vacillate between trophy and ethnographic documents, annihilating somehow the decorative panels, transforming an intimate space into a rather chaotic exhibition-cum-commemoration room.

It is the same with the photographs of the places given over to the senior officers' lodgings in the garrison of Constantine: they show either interiors that are completely European (fig. 9), conceived like centripetal sanctuaries, cut off from their local envi-

30 Féraud, Monographie du Palais du Bey, 50. 


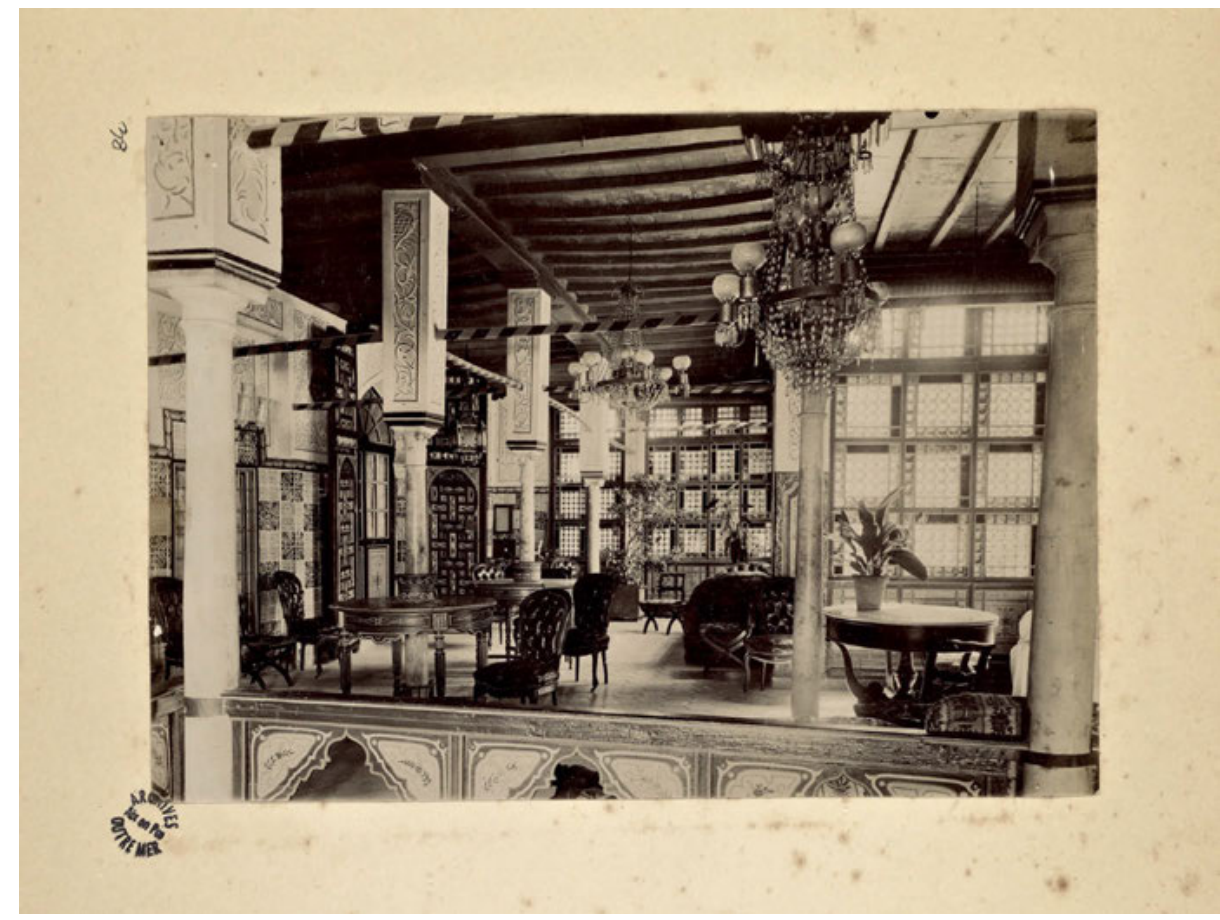

Fig. 10: Vestibule of the Chamber of the Princess, Ahmed Bey Palace, Constantine, state ca. 1860-1870, ANOM, FR ANOM 8Fi444/38.

ronment, or temporary arrangements where the furniture, emblematic of contemporary European bourgeoisie (armchairs, pedestal tables, etc.) sits in a decorative setting that has conserved its Ottoman-Maghrebi spirit, in spite of the modifications (fig. 10). Contrary to the boundary interiors of Ahmed Bey's time where imported foreign and indigenous elements contributed to what we could call a poetics of hybridity, these colonial interiors are made up of metropolitan identity elements transposed into a setting perceived as exotic by their owners. They are the demonstration of a divided mode of habitat, a melancholic experience of heterogeneity that is the direct echo of an identity crisis where confrontation with otherness is marked by a double bind, demanding of the new inhabitants both fascination and desire of occultation. The habitat here is inseparable from a feeling of exile, patrimonial admiration inseparable from a kind of aggressive resentment, so that the pre-colonial situation, while being deliberately disfigured, remains present, protected partly by the paradox of nostalgia. 


\section{Promoting National Authenticity}

After independence of the country in 1962, and especially after the exit of the Algerian army that takes its leave in 1969 , the definite objective is that of a real patrimonialization of the whole architectural conspectus that brings it back as an exceptionally successful emblem of Ottoman-Algerian culture-as close as possible to its original state, as it was on the eve of the French invasion. As such, the restoration program foresees the eradication of the French additions; it is this aim that prevails during the first restoration campaign, carried out by a Polish team from April 4, 1984, to September 27, 1985. This resolution remains unchanged during later refurbishments, taken over by Algerian experts from 2002 on, and in the most recent projects: the last one to date, under the authority of the Spanish agency EMR (Estudio Métodos de la Restauración) promising thus to pass from 44\% "authentic Ottoman" wall paintings to $90 \%$, after restoration. ${ }^{31}$

Logically, the patrimonialization of the monument goes hand in hand with its being inserted into a museum context that continues in the same anticolonial objective, by creating inside the palace, a museum of the "arts and expressions of traditional culture" before the French conquest, as is explicitly announced in the founding decree of the museum in 2010. The choice of the Ahmed Bey palace as the site for this national museum is justified by the fact that it "expresses better than any other place in the city a remembrance consisting of signs and images of resistance, from the rich and diversified period that was the Ottoman one, a real synthesis of multiple influences from the Mediterranean basin valorizing the Algerian genius through artistic expression such as architecture and artisanal and pictorial creation” (fig. 11); and one of the missions the museum itself has is "the implementation of a data base on the traditions, personalities and the history of the town and its region from the sixteenth century up to 1837."32

In doing this, it no longer means implementing hybridity in the present, but staging the as-faithful-as-possible image of a past hybridity, with the guarantee of historical authenticity ensured by a two-fold patrimonial and museum policy, centered round the Beylical period. As in any patrimonial process, this quest for authenticity fixes what was fluid and composite in nature, the original movement of forms. Interaction between the aesthetic complexity of the palace and the social and political life during Ahmed Bey's tormented epoch gives way to the exhibition of a bygone state of forms and society, by the intermediary of forms that are restored and conserved as fixed markers of the past. This past is thus transformed into image, in other words

31 Projet d'intervention sur les peintures murales. Palais Hadj Ahmed Bey, Constantine (Algérie), ed. Marcos Roca Ramón (Valencia: Moncada, 2013), n.p.

32 Executive decree no. 10-262 of the Dhou El Kaada 1431 (October 21, 2010), specifying the creation of the Musée National des Arts et Expressions Culturelles Traditionnelles de Constantine. 


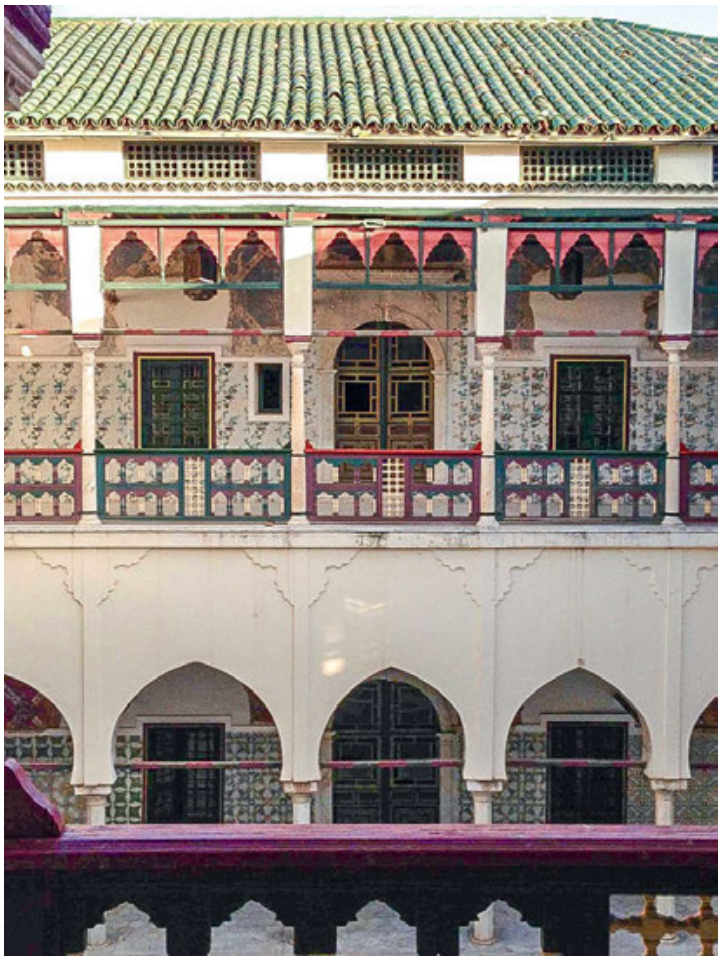

Fig. 11: Harem Courtyard.

idealized, by splitting it as far as possible from the traces of the colonial violence. Even if it no longer puts a poetics of hybridity into action, the restored palace and its museum have the role of designating it in a process of space transformation where the historical knowledge on the Ottoman period, cleared of subsequent aggression and obfuscation, overrides the actual experience, just as informative reading and distanced observation aim to take the place of immediate social customs.

In a little less than two centuries, the palace has adhered to three very different symbolic economies: Beylical Algeria, personifying a composite culture in the present where the diversity of its forms is in constant interaction; colonial Algeria, where a regime in crisis between past and present pits vernacular representations against European adjuncts, the latter violently imposing in its heterogeneity; and thirdly, Algerian nation, where a quest for authenticity means recovering the hybridity of its origins-but as a fixed image of an ideal past. This last aim reflects the contradiction inherent to any patrimonialization: it preserves the existence of a place only to deprive it of its functional, concrete allegiance to the present.

In the case of the Ahmed Bey Palace, however, the will to celebrate an "authentic Ottoman" past clashes with the essence of the building itself, its very structure being little adapted to a classical museumification. Naturally, with its courtyard gardens, covered galleries, and apartments, it appeals to the visitor more as a promenade than 
a place of actual learning, with feelings related to gardens and private interior spaces, becoming just as important as thoughtful observation. Over and above the exhibiting itself, traditional cultural activities such as concerts, festivals, etc. regularly take place in these interlocked spaces, dynamized by the naturally performative scope of the place.

This de facto resistance of cultural hybridity also results from the fact that it is impossible to achieve a real purge of the building by unravelling the Ottoman content from its numerous and complex colonial trappings-even if the latter are henceforth clearly identified. Therefore, the real question is whether, in the context of a visit to the museum, the colonial stratum is interesting today for Algerian society. Even if, as historical testimony, it deserves not to be erased, it is, on the contrary, foreign to the subtle charm of the palace that evokes life, both in the gardens and in the whole setting: the colonnaded galleries that protect it from heat and rain, the inscriptions provoking food for thought, etc. On the whole, this architecture, conceived on a human scale, still continues to arouse the same feelings that were felt by the French, in particular writers and artists (the Vernets, Gautiers, Maupassants, and the like), visiting the place in the nineteenth century. Bearing this in mind, one can credit a conscious poetics of hybridity with managing to have a simultaneous aesthetic and political effect up to the present day, while triumphing at once over the great colonial damage and the threats of paralysis that are the risks of all purifying patrimonialization.

Translated from the French by Maureen O’Hare Wilson 
